\title{
O ACESSO À INFORMAÇÃO GENÉTICA E A CONFORMAÇÃO DOS NOVOS DIREITOS DA PERSONALIDADE: O ALCANCE DA PROTEÇÃO À IDENTIDADE GENÉTICA SOB A PERSPECTIVA DO DIREITO CIVIL CONTEMPORÂNEO
}

RESUMO: Artigo destinado à análise da conformação do direito à identidade genética como uma espécie dentre os novos direitos da personalidade considerando o direito civil contemporâneo. O objetivo da pesquisa é descortinar o alcance da proteção à identidade genética a partir das diferentes situações que podem envolver a proteção ao bem jurídico em destaque. Como caminho metodológico, usou-se a abordagem lógico-dedutiva, a fim de identificar por meio de dedução a melhor interpretação no que tange à construção da proteção do direito.

Palavras-chave: identidade genética; direito da personalidade; informação genética; direito civil contemporâneo; novos direitos.

\section{ACCESS TO GENETIC INFORMATION AND THE CONFORMATION OF NEW PERSONALITY RIGHTS: THE SCOPE OF PROTECTION TO GENETIC IDENTITY UNDER THE PERSPECTIVE OF CONTEMPORARY CIVIL LAW}

ABSTRACT: This paper aims to analyze the conformation of the right to genetic identity as a species among the new rights of the personality considering contemporary civil law. The objective of the research is to uncover the scope of the protection of the genetic identity from the different situations that may involve the protection of the legal good in focus. As a methodological path, the logical-deductive approach was used in order to identify by means of deduction the best interpretation regarding the construction of the protection of the right.

Keywords: genetic identity; right of personality; genetic information; contemporary civil law; new rights.

\section{INTRODUÇÃO}

A possibilidade de acesso à informação genética contida no DNA humano é descortinadora de um plexo de situações que demandam reflexões de natureza ético-jurídica. Centra-se a proposta justamente nas consequências de tal acesso, partindo do reconhecimento fundamental da individualidade humana como um bem jurídico, revelada pela proteção à

*1 Doutora em Relações Sociais e Novos Direitos pela Universidade Federal da Bahia (UFBA). Mestre em Direito Privado e Econômico pela Universidade Federal da Bahia (UFBA). Professora das disciplinas Biodireito, Bioética, Direito Civil e Metodologia da Pesquisa Jurídica da Universidade Católica do Salvador (UCSal), da Universidade do Estado da Bahia (UNEB) e da Faculdade Baiana de Direito. Contato: anatherezameirelles@gmail.com. 
personalidade.

A informação genética então acessível conforma novos direitos da personalidade, nitidamente entrelaçados por essência, como a identidade genética, a intimidade e privacidade genéticas e a não discriminação genética. $\mathrm{O}$ foco proposto está na identidade genética por ser considerado o mais extensivo dentre tais direitos, tendo em vista relacionar-se com os outros de maneira expressivamente significativa. Dessa forma, sabe-se que a abordagem do conteúdo da identidade genética pode manter-se relacionada com as manipulações biológicas em geral, que se conformam de diversas maneiras, consoante, a exemplo, o previsto na lei brasileira de biossegurança.

O direito civil contemporâneo, como partidário da proteção central à pessoa humana, passou a refletir sobre a teoria dos direitos da personalidade de modo a abranger a realidade biotecnológica e médica que emerge da proposta científica atual. A partir do momento em que a informação genética do ser humano passa a ser um dado acessível, torna-se necessário disciplinar as condutas que podem violar a proteção da personalidade, atualmente interpretada sob a ótica de diferentes dimensões.

O objetivo proposto assenta então em analisar o alcance da proteção da identidade genética considerando os espectros possíveis que envolvem a realização de condutas distintas, e fulcrada no fato de ser ela parte integrante da personalidade humana, portanto, merecedora de tutela. A identidade genética passa a ser avaliada a partir do direito à irrepetibilidade, à integridade, ao segredo e ao conhecimento, circunstâncias que podem estar delicadamente relacionadas.

\section{O ACESSO À INFORMAÇÃO GENÉTICA: EXAMES E DIAGNÓSTICOS POSSÍVEIS}

O acesso à informação genética é descortinador de uma série de novas situações relacionadas aos direitos da personalidade. Com o fito de compreender essa nova dinâmica, torna-se essencial a contextualização desses novos avanços em sede de genética e biotecnologia, manifestados pela medicina diagnóstica, a partir de informações que detalharão o estado atual do conhecimento humano relacionado à temática.

A possibilidade de acessar a constituição da essência da vida humana faz exsurgir novas questões éticas, de modo que empreender qualquer ação nesta área demanda a 
contabilização das consequências antes de praticá-la, por meio da razoabilidade, da prudência e do bom senso. Para Hans Jonas, as consequências do uso dos poderes devem ser previstas em momento precedente à constatação de que eles estão prontos para serem usados (JONAS, 1994, p.63-64). A possibilidade de praticar uma conduta não a torna imediatamente moralmente aceita ou juridicamente admitida. Este pressuposto deve restar esclarecido quando a questão versar sobre o acesso à informação genética, já que as condutas neste plano estão nitidamente associadas à possibilidades arriscadas, que tenham como consequência a violação de direitos da pessoa humana, como a intimidade, a privacidade, a saúde, a identidade e a igualdade.

A possibilidade de ter acesso a determinadas informações da constituição da vida humana, por meio de diagnósticos ou manipulações biológicas, não pode, por si só, ser considerada um fator autossuficiente, ou seja, não deve ser praticada simplesmente porque a Ciência a recepcionou como uma conduta viável. Essa tensão é resumida pela difícil tarefa de conciliar de forma coesa as descobertas da Ciência, possibilitando a consecusão de seus avanços, com os pressupostos fundamentais da Ética, precipuamente sinalizados por Van Potter (POTTER, 1971; POTTER, 1988).

A classificação dos mecanismos de transmissão hereditária foi possibilitada pela descoberta do DNA em 1944. Na sequência, em 1953, James Watson, juntamente com outros cientistas, descobriu a sua estrutura helicoidal dupla, que contém a informação genética que propicia a codificação das características do indivíduo (BARTH, 2005).

Las consecuencias básicas y aplicadas que se han derivado de la identificación del ADN como material hereditario son de tal envergadura que ha supuesto un cambio de paradigma pocas veces igualado en la historia de la Ciencia. Se puede decir que en la historia de la Genética hay un "antes del $A D N$ " y un "después del $A D N$ " que la dividen en dos lapsos de tiempo más o menos equivalentes: desde 1865 en que Mendel hizo públicos sus experimentos y 1900 en que se "redescubren" las leyes de Mendel hasta 1944 - el "antes del ADN"- y desde 1944 hasta nuestros días, el “después del ADN” (LACADENA, 2011, p.8).

Variados benefícios foram concretizados a partir da descoberta do DNA, como a obtenção de novos medicamentos "a partir do momento em que os cientistas começaram a utilizar a tecnologia do DNA recombinante para misturar e equiparar pedaços e peças de material hereditário”. Foram também descortinadas informações genéticas relacionadas à perturbações da leitura (associadas ao cromossomo 15) à esquizofrenia (cromossomo 5), à psicose (cromossomo 11) e psicose maníaco-depressiva (11 e X). Descobriu-se a ligação 
O ACESSO À INFORMAÇÃO GENÉTICA E A CONFORMAÇÃO DOS NOVOS DIREITOS DA PERSONALIDADE: O ALCANCE DA PROTEÇÃO À IDENTIDADE GENÉTICA SOB A PERSPECTIVA DO DIREITO CIVIL CONTEMPORÂNEO

genética entre o alcoolismo e o gene mutante para o receptor dopamina 2, também associado ao autismo, à síndrome de Tourett, à dependência química e à hiperatividade (BARBAS, 2007, p.47).

Com o início do projeto Genoma Humano, em 1986, foi criada a HUGO (Human Genome Organisation) com o objetivo de "promover a coordenação e cooperação internacional do Projeto Genoma Humano”, constituída por quarenta e dois membros de nacionalidades diferentes. A organização é um órgão de consulta, não tem fins lucrativos e objetiva propiciar a cooperação global e fornecer as informações descobertas relacionadas ao conhecimento genético (BARBAS, 2007, p.49).

O Projeto Genoma portou-se como um marco de transformação da relação do homem com a informação de natureza genética. Os avanços alcançados simbolizam a transformação das possibilidades diagnósticas relacionadas à conformação de patologias múltiplas. O Projeto anunciou em abril de 2003 a descodificação de 99.9\% do genoma e a existência de 30 mil genes humanos, mas o trabalho ainda não está definitivamente concluído. A síntese dos principais objetivos do Projeto pode ser captada pela proposta de mapeamento e análise do genoma com a finalidade de obter a sua sequência ordenada para, então, identificar o que determina as enfermidades, comprovando a função dos genes na etiologia e na patogenia da doença. Disso resulta a possibilidade de desenvolver e melhorar os exames que possam ser usados na sequência do DNA e dos testes genéticos, de forma a criar formas de aperfeiçoamento para reparação ou substituição dos genes que apresentem indicadores patológicos (BARBAS, 2007, p.56 e 75).

O Projeto Genoma corroborou o desenvolvimento e a ascensão da medicina preditiva, que visa à prevenção da manifestação de uma determinada patologia com certa antecipação.

Con el desarrollo del PGH, la medicina há entrado en una nueva era, la llamada “medicina genómica”, que se caracteriza por un rol más preventivo que curativo. En esta era, los tests genéticos preventivos tienen un rol preponderante, ya que permiten realizar un screening de las mutaciones que posee una determinada persona, para informarle de los riesgos específicos de contraer patologías específicas en el futuro o, incluso, detectar enfermedades antes del nacimiento, desde el estado embrionario y fetal”' (ALCÂNTARA, 2004, p.192).

Muitas doenças passaram a ser conhecidas, sendo que já “foram inventariadas mais de quatro mil espécies de alterações genéticas e que algumas delas correspondem a doenças hereditárias com grande incidência”. Testes genéticos já propiciaram o diagnóstico de 
doenças como fibrose quística, Alzheimer, Tay Sachs, hemofilia, deficiência alfa-1antitripsina, esclerose lateral amiotrófica, ataxia talangectasia, gaucher, cancro de ovário, da mama, e do cólon hereditário, hiperplasia adenal congénita, distrofia muscular de Duchenne, distonia, anemia de Falconi, síndroma X-frágil, neurofibromatose de tipo I, fenilcetonúria, doença poliquística renal entre outras (BARBAS, 2007, p.86). A medicina preditiva prevê, com muito pequena margem de erro, o aparecimento futuro, a largo prazo, por exemplo, em décadas, de manifestações de enfermidades. Especula-se que poderá ser previsto que determinado embrião, feto ou pessoa venha a sofrer, daqui a alguns anos, desta ou daquela doença, no entanto, ressalta-se que, se o diagnóstico for de predisposição, a previsão poderá ser de extremo interesse para o diagnosticado, que poderá mudar o seu estilo de vida, modificando seu comportamento, para fins profiláticos por exemplo. Se as doenças não forem curáveis e nem influenciáveis pela profilaxia, o valor da informação genética preditiva parece ser consubstancialmente reduzido (OSSWALD, 2005, p.20), já que substancialmente alterará a conformação da vida das pessoas, fazendo com que muitas sequer tenham desejado ter acesso a tal condição genética.

\begin{abstract}
Una de las características más peculiares de la información genética es su capacidade predictiva, pues su anticipación puede abarcar incluso enfermedades respecto a las cuales el individuo es todavía asintomático, es decir, cuando ni siquiera está padeciendo la enfermedad o todavía no ha manifestado sus primeros síntomas en el momento en el que se somete a las pruebas analíticas pertinentes. Esta capacidad predictiva es especialmente significativa en relación con las enfermedades monogénicas, de las que es responsable um solo gen deletéreo, bien dominante (basta com que uno de los dos heredados de ambos progenitores sea defectuoso para que la enfermedad aparezca), bien recesivo (sería necesario que ambos progenitores transmitiesen el gen deletéreo para que se manifestase la enfermedad; si sólo lo transmite uno de los padres, el hijo será sano, pero portador de la enfermedad, que podrá a su vez transmitir a sus propios hijos). Pero lo es menos en relación con las enfermedades plurigénicas en las que, además de intervenir varios genes, incluso situados en cromossomas diferentes, es necesaria la concurrencia de otros factores exógenos o ambientales (por ello se conocen como enfermedades plurifactoriales), en ambos casos por mecanismos no bien conocidos en la actualidad y por ello se habla en sentido más propio de susceptibilidad o predisposición para padecer la enfermedad. (CASABONA, 2002, p.285)
\end{abstract}

Ressalta-se, neste contexto, a necessidade de compreender as doenças a partir da ótica multifatorial, pois, conforme alertado, o ambiente também é responsável pela manifestação delas. "Fatores ambientais, tanto os ligados ao estilo de vida quanto os decorrentes de exposições nos locais de trabalho ou no ambiente geral, têm influência distinta sobre os indivíduos com relação ao risco de determinadas doenças” (SEGRE; GATTÁS; 
WUNSCH FILHO, 2002, p.160).

O alcance do conhecimento sobre o código genético implica na necessária consciência de algumas questões. Nenhum estudo neste campo comprovou que a composição genética é o único fator responsável pela constituição da natureza humana. Ainda não há elementos que corroborem o determinismo gênico do comportamento humano, posto que é difícil "demonstrar associações entre variantes genéticas específicas e traços comportamentais" (CASTIEL; CARDOSO, 2003, p.654 e 656).

Em termos individuais, não há dúvidas dos benefícios trazidos em torno da prevenção de doenças que podem se manifestar no futuro, pois, o fato de conhecer as próprias predisposições genéticas pode conduzir a uma mudança de comportamento, no sentido de afastar fatores ambientais que possam interagir e contribuir para a incidência da patologia (KUTUKDJIAN, 2004, p.117). O mapeamento alcançado torna possível a identificação de genes "responsáveis por doenças, assim como a suscetibilidade a determinadas doenças profissionais; a determinados climas; a determinadas alergias e a outros riscos, além de detectar portadores assintomáticos de disfunções genéticas que podem ser transmitidas para os descendentes.” (SCHRAMM, 2006, p.12).

Daniel Cohen, um dos pesquisadores em destaque atuantes no desenvolvimento do Projeto Genoma, afirma que é necessário distinguir um "eugenismo positivo que consiste em querer crianças 'melhoradas', o que, no estágio atual de nossa compreensão do ser vivo e da evolução social, só desemboca, na maioria das vezes, em delírios de caráter racista e nazista”; e, do outro lado "um eugenismo negativo, que consiste tão somente em evitar o nascimento de crianças que, sabemos, serão gravemente doentes e apresentarão handicaps sérios” (COHEN apud SCHRAMM, 2006).

O eugenismo ou a neoeugenia, para empregar uma terminologia contemporânea, é a possível e real consequência de um uso ilimitado da informação genética. O acesso à informação genética propicia o descortinar de um elemento de constituição humana que enseja consequências delicadas, quando manejado de maneira inapropriada. A primeira justificação do uso desmedido da informação de natureza genética pode ser identificada no plano da condição de saúde, ou seja, a priori, é possível justificar todas as intervenções ou acesso às informações de natureza genética a partir da motivação terapêutica. A questão não é 
tão simples quanto parece ser, já que a constituição genética de cada indivíduo hoje também integra parte de sua condição elementar e consequentemente de sua personalidade.

O acesso à informação genética é conduta desveladora de parte da essência de cada ser humano, não estando disponível a toda e qualquer pessoa ou a instituição empresarial ou estatal. Enquanto elemento integrante da condição essencial do ser humano, merece proteção por resvalar em direitos normativamente assegurados.

A proteção à personalidade da pessoa está hodiernamente configurada sob o molde de novos arranjos ao considerar situações que podem trazer implicações novas. A evolução da Genética e consagaração da Medicina de função preditiva passaram a contribuir para essa nova configuração protetiva dos direitos da personalidade, na medida em que possibilitam a consecusão de ações que tocam na essência da constituição da natureza do ser humano.

\section{OS NOVOS DIREITOS DA PERSONALIDADE RELACIONADOS À GENÉTICA}

A relação da Genética com a personalidade humana parte de uma análise que aponta para uma perspectiva de natureza constitucionalizada. A ligação entre direitos fundamentais e direitos da personalidade, exaustivamente proposta doutrinariamente, evidencia que o acesso à informação genética tangencia questões atinentes aos espectros público e privado. Direitos humanos, direitos fundamentais e direitos da personalidade manifestam-se como prospecções protetivas ontologicamente próximas, de modo que também podem estar relacionados com as consequências da proposta da Genética na atualidade. Mesmo em âmbitos de proteção distintos, pode-se perceber que o cerne da tutela é o ser humano ontologicamente considerado, em suas necessidades existenciais e materiais.

Assim, também pode-se registrar que a entrelaçada relação existente entre direitos humanos, direitos fundamentais e direitos de personalidade tem como diferença objetiva o plano de manifestação da personalidade humana, pois, os direitos humanos estão sediados e reconhecidos em documentos internacionais, os fundamentais nas Constituições democráticas e os de personalidade nas relações de natureza privada (SCHREIBER, 2011, p.13).

A construção dos direitos da personalidade adveio da necessidade de conferir proteção à personalidade humana, considerando a situação da humanidade no período pósguerra onde passou-se a falar na existência de um “direito geral de personalidade” (CAPELO 
O ACESSO À INFORMAÇÃO GENÉTICA E A CONFORMAÇÃO DOS NOVOS DIREITOS DA PERSONALIDADE: O ALCANCE DA PROTEÇÃO À IDENTIDADE GENÉTICA SOB A PERSPECTIVA DO DIREITO CIVIL CONTEMPORÂNEO

DE SOUSA, 1995), com vistas à colocação da pessoa no centro das relações jurídicas. A Constituição Federal de 1988 consagrou os direitos da personalidade em normas esparsas e o Código Civil de 2002 disciplinou, especificadamente, a matéria entre os artigos 11 a 21, passando a compor então um dos principais assuntos da doutrina hodierna e um dos pontos de fundamental importância do Direito Civil contemporâneo.

O fio que relaciona os diferentes âmbitos de proteção jurídica do ser humano é a dignidade da pessoa humana, essencial à discussão em tela. Trata-se de um valor intrínseco inerente à condição de ser humano que tem como fundamento primordial o reconhecimento de sua autonomia existencial e de sua dimensão espiritual. A dignidade, enquanto um conceito plúrimo, polissêmico e de difícil aferição, está nitidamente imbricada com a possibilidade de acessar a informação genética. O conteúdo do DNA humano também é parte integrante da autocompreensão pessoal, é algo que é capaz de descortinar complexas interpretações em torno de si mesmo e pertence portanto à uma esfera de intimidade.

Numa leitura rápida sobre a linha de pensamento kantiano, a qualidade de ser humano automaticamente implica no reconhecimento de sua dignidade, adquire-se, juridicamente, a dignidade apenas pelo simples fato de ser humano. Não se pode mais contestar que a primazia da pessoa humana "corresponde não só a uma das reivindicações mais profundas do homem, mas, sobretudo, a uma exigência ética”. Sendo assim, para Kant, a dignidade humana "não reside em deixar suas ações e sua existência conformes com a lei eterna, ou seja, com a ordem de Deus, [...] mas em seu estatuto de agente racional. Existe em cada homem um direito a dignidade, porque há identicamente em todos os indivíduos um mesmo potencial humano racional” (RIVERO; MOUTOUH, 2006, p.343).

Para Ingo Wolfgang Sarlet, a mudança de paradigma do fundamento do Direito Natural (de um direito de ordem divina a um direito racional) fez com que a concepção de dignidade humana passasse por um processo de racionalização e laicização, sem, naturalmente, abandonar a noção de que todos os homens são iguais em dignidade (SARLET, 2001, p.32). Nesse liame, sendo um atributo inerente a todos os seres humanos, a dignidade independe de origem, raça, cor, sexo ou quaisquer outros requisitos. Logo, também não admite discriminações calcadas em análises genéticas de probabilidades que possam revelar características físicas, condições psíquicas ou patologias. O sentido construído ao longo dos 
tempos para a dignidade humana como um valor jurídico precisa também ser preservado pela dinâmica das intervenções e manipulações de natureza genética.

A proteção à pessoa humana, no âmbito das relações sociais que ela pode integrar, parte do reconhecimento da importância das projeções de sua personalidade, como a vida, as integridades física e psíquica, a honra, a imagem, a intimidade e o nome. Os direitos da personalidade são, portanto, o objeto das relações e situações jurídicas, posto representarem o reconhecimento normativo das projeções humanas. Se toda pessoa é titular de personalidade jurídica, pode ela exigir e defender os direitos atinentes à conformação de sua existência.

Delineando sua conceituação, os direitos da personalidade estão domiciliados na esfera mais íntima da pessoa, pois, consistem na proteção dos atributos da personalidade humana (SZANIAWSKI, 2005, p.19). Segundo Roxana Borges, são “projeções físicas ou psíquicas da pessoa, ou as suas características mais importantes. As projeções da personalidade, suas expressões, qualidades ou atributos são bens jurídicos e se apóiam no direito positivo.” (BORGES, 2007, p.20). Ana Carolina Brochado Teixeira (2010, p.205) entende que tais direitos são como uma "projeção de algum aspecto da personalidade em espaços de subjetividade e intersubjetividade, que deve ser tutelado pelo Estado na medida da necessidade individual, de acordo com os valores que a própria pessoa estabeleceu como prioritários”.

Os direitos da personalidade não podem ser concebidos como numerus clausus, posto que se referem à proteção plena da personalidade humana, constituindo-se de forma dinâmica e em natural expansão. Esta perspectiva é corroboradora do desenvolvimento da sociedade e das potenciais possibilidades advindas da evolução da biotecnologia, que podem ocasionar violações e prejuízos à pessoa humana. A concepção da existência de direitos desta natureza deve partir da compreensão de uma perspectiva aberta de sistema jurídico (HÄBERLE, 2002), consoante o surgimento de novos direitos ligados à personalidade humana, como os direitos à identidade genética, à intimidade genética e a não discriminação genética.

A informação genética é capaz de revelar as predisposições genéticas dos indivíduos e também de promover a identificação da pessoa. Os dados genéticos relativos a um ser humano conformam a sua individualidade e são, portanto, únicos, preditivos, estruturais, probalísticos e geracionais. São únicos posto serem reveladores de informações genéticas do 
ser humano enquanto espécie, o que constitui, sob este espectro, parte integrante do patrimônio genético natural da humanidade; são estruturais por traduzirem características específicas de uma pessoa, diferenciando-a das outras, tornando-a singular; probabilísticos pela potencial capacidade de apontar as possibilidades do desenvolvimento de alguma enfermidade ou patologia; e são, também, geracionais porque evidenciam a herança genética do indivíduo e sua relação com a cadeia de ascendência (HAMMERSCHMIDT, 2008, p. 1720).

Corroborando a perspectiva exposta no sentido de relacionar a informação genética com a conformação sistêmica dos direitos da personalidade, acrescente-se que tal informação pode traduzir-se em predição do futuro (potencial habilidade de apontar predisposições a doenças); informação secundária (quando a proposta tem alguma relação entre a informação obtida geneticamente e a resposta a alguma medicamento); e informação sobre a origem biológica (determinação da ascendência genética) (EMALDI CIRIÓN, 2001, p. 201).

Sabe-se que a evolução do acesso ao conhecimento em Genética proporcionou ao processo penal a utilização do DNA, permitindo definir com melhor precisão as diferenças entre as pessoas para constituição da prova do crime. Assim é sabido que a informação genética é de extrema valia para a consecusão da medicina legal moderna, revolucionando o curso das investigações criminais.

Enquanto informações obtidas, ou passíveis de se obter, do DNA e RNA humanos, deve-se, conforme Bruno Torquato e Maria de Fátima Freire de Sá, esclarecer que “a proteção jurídica não se faz presente apenas quando o material genético é transformado em informação; a mera potencialidade de se converter em informação já produz efeitos jurídicos”. Prossegue os autores afirmando que "o dado genético e material genético não são coincidentes; aquele é o resultado da transformação deste em informação ou, ao menos, a potencialidade de transformar o material genético em informação”(TORQUATO; SÁ, 2012, p.244).

Considerando as características dos direitos da personalidade já tradicionalmente conhecidas (necessidade; extrapatrimonialidade; intransmissibilidade; indisponibilidade; vitaliciedade e outras), para comprovar a estreita relação entre eles e os dados genéticos, os autores fazem interessante reflexão:

Há, aparentemente, perfeita correspondência entre os dados genéticos, a definição e as características dos direitos de personalidade. Aqueles são informações vitais para o desenvolvimento da vida humana; são necessários, já que toda a matéria viva é regida, biologicamente, pelas informações de seus genes; são vitalícios, pois se 
constituem em bens que acompanham o curso da vida humana; são indisponíveis e intransmissíveis, pois sua disposição ou transmissão implicaria na cessação da vida de seu titular; e, por fim, são extrapatrimoniais, devido à impossibilidade de avaliação econômica, por isso são considerados bens fora do comércio (TORQUATO; SÁ, 2012, p.244).

O surgimento de novos direitos da personalidade relacionados aos dados genéticos aponta para conformá-los em três possibilidades: a identidade genética, a ser tratada de maneira aprofundada no próximo capítulo, a intimidade genética e a não discriminação genética.

O direito à intimidade e privacidade genéticas conformam-se pelas vedações às exigências de mapeamentos ou testes preditivos para fins empregatícios ou contratuais, que podem envolver situações admissionais e alocação de funções específicas ou a conformação de contratos de plano de saúde (HAMMERSCHMIDT, 2008; ECHTERHOFF, 2010). A não discriminação genética (LIMA NETO, 2008), como um direito de personalidade, conforma a proibição do uso da informação genética para fins segregacionistas ou discriminatórios aplicáveis em qualquer relação social, considerando a necessária proteção da dignidade dos seres humanos, violada em caso de etiquetamento proveniente das probalidades genéticas que os mesmos carregam em seu DNA.

\section{O ALCANCE DA PROTEÇÃO À IDENTIDADE GENÉTICA SOB A PERSPECTIVA DO DIREITO CIVIL CONTEMPORÂNEO}

A identidade genética enquanto novo direito emanado da personalidade humana pode ser projetada a partir de distintas conformações por envolver situações diferentes. Em verdade, a precisão de seu conteúdo tem sido constantemente apontada pela doutrina a partir da relação com outros direitos novos ligados à personalidade atinentes ao acesso à informação genética. Pode-se então entender que o esclarecimento do conteúdo do direito à identidade genética demanda aportar todas as situações que possam de alguma maneira manter relação com o bem jurídico em foco. A identidade genética pressupõe o direito de não ser repetido, ou seja, de não ser clonado; o direito de manter em resguardo o conteúdo da informação genética pessoal; o direito de não submissão à práticas de engenharia genética; e, por fim, ainda o direito de conhecer a identidade ou origem genética (a ascêndencia biológica). São, portanto, desdobramentos que precisam de detalhamento posto que podem restar também confundidos 
O ACESSO À INFORMAÇÃO GENÉTICA E A CONFORMAÇÃO DOS NOVOS DIREITOS DA PERSONALIDADE: O ALCANCE DA PROTEÇÃO À IDENTIDADE GENÉTICA SOB A PERSPECTIVA DO DIREITO CIVIL CONTEMPORÂNEO

com os direitos à intimidade genética e a não discrimnação genética.

A proteção à identidade genética do ser humano tem sua construção assentada na perspectiva de defesa e prestação. Cabe ao Estado então respeitar a autonomia da pessoa em geral, abstendo-se de interferências arbitrárias, e, ao mesmo tempo, agir de maneira interventiva quando restar consolidada a violação do bem jurídico.

A compreensão do conceito de identidade genética a partir da ideia de clonagem está no resguardo à integridade do patrimônio genético de cada ser humano, devendo manter-se intangível no que tange à possibilidade de repetição. A questão demanda o esclarecimento quanto os dois tipos de clonagem possíveis: a reprodutiva, que origina um ser humano geneticamente igual a outro, e a não reprodutiva, que busca a obtenção de órgãos e tecidos para fins terapêuticos.

A a lei 11.105/2005, lei de biossegurança, proibiu a prática da clonagem humana, sem especificar se apenas estaria restringindo a prática da clonagem à finalidade reprodutiva. Conforme depreende-se do conteúdo legislativo, a proibição abrange também a clonagem para fins terapêuticos, alvo de críticas por parte da doutrina especializada (PRADO; HAMMERSCHMIDT, 2017), já que sua finalidade seria a promoção da saúde através da extração de células-tronco para, a longo prazo, obter tecidos e órgãos.

Pode-se concluir então que, quanto à clonagem reprodutiva, cumpriu o seu papel o Estado brasileiro quando proibiu a prática do procedimento, preservando a identidade genética do ser humano a partir do seu direito de não ser repetido. No que tange à proibição extensiva à clonagem não reprodutiva, a controvérsia persiste, tendo em vista que, neste tipo de procedimento, não há o objetivo de implantação do embrião clonado para geração futura do clone. O escopo da clonagem terapêutica é a obtenção de tecidos e órgãos, a partir dos embriões, que, na atualidade, é realizada ainda em alguns países sob a forma de pesquisa, ou seja, demanda estudos pela medicina especializada. É necessário atentar que a lei brasileira de biossegurança permitiu que embriões humanos excedentes aos processos de fertilização em laboratório fossem destinados a pesquisas científicas, apontando para um tratamento que relativiza a integridade da vida humana embrionária em estágio de não implantação. Há quem critique a vedação à clonagem terapêutica justamente por compreender tratar-se de antinomia normativa, já que no Brasil embriões não implantados podem ser destinados à pesquisas científicas quando manifestado o consentimento de seus genitores. 
A proteção à identidade genética a partir do direito de manter em resguardo o conhecimento do conteúdo do DNA mantém óbvia relação com que o que se entende hoje como direito à privacidade e intimidade genéticas. No entanto, pode-se pensar também que a relação com a identidade é facilmente aferida. Selma Pertele aponta para o direito de "não ter a identidade genética revelada através de testes genéticos, salvo em benefício à saúde da pessoa testada” (PERTELE, 2007, p.115).

A possibilidade de realizar testes ou diagnósticos genéticos traz consigo realidades distintas que merecem observação e cuidados também diferenciados. O crescimento de tais possibilidades, impulsionado pelo Projeto Genoma, tem seu ápice nas realizações diagnósticas, que podem ter finalidade apenas de aconselhamento pessoal ou familiar ou ainda de procriação. A medicina preventiva é uma consequência direta da medicina preditiva, posto que, primeiro se prediz ou se anuncia o que pode se suceder no futuro de um indivíduo, para que, posteriormente, se possa promover a prevenção, antecipando a preparação de uma resposta ou um tratamento àquilo que se anunciou (EMALDI CIRIÓN, 2001, p.10).

Os testes ou diagnósticos genéticos não podem ser realizados sem que reste manifestada com nitidez o consentimento do diagnosticado. A informação genética é reveladora de conteúdo de natureza íntima que pode, inclusive, não somente apontar indícios de uma patologia física, mas, também comprometer a saúde psíquica de uma pessoa. Lidar com o conteúdo de uma informação genética demanda um preparo pessoal e sobretudo o elemento volitivo, a vontade de conhecer o conteúdo a ser revelado.

Os testes ou diagnósticos genéticos também são comumente chamados de aconselhamentos genéticos e podem ser feitos com vistas a diferentes finalidades. Os profissionais aconselhadores devem repassar a informação genética isenta de valores pessoais ou julgamentos que possam direcionar sua compreensão. O reconhecimento da neutralidade moral do aconselhador em face da informação genética confirma o fato de que "o aconselhamento genético não é mais um instrumento de higiene social servindo a ideais eugênicos, mas uma peça educativa fundamental à promoção da saúde pública e dos direitos humanos” (DINIZ; GUEDES, 2009, p.249).

O teste ou aconselhamento pode ser feito sem que o paciente esteja com intenção de procriação, apenas com o objetivo de identificar a possibilidade de incidência da doença em si próprio ou em familiares, mas, também pode representar uma finalidade procriativa. Chamado 
O ACESSO À INFORMAÇÃO GENÉTICA E A CONFORMAÇÃO DOS NOVOS DIREITOS DA PERSONALIDADE: O ALCANCE DA PROTEÇÃO À IDENTIDADE GENÉTICA SOB A PERSPECTIVA DO DIREITO CIVIL CONTEMPORÂNEO

também de teste genético (screening), sobre ele recaem as discussões em torno do uso adequado da informação genética em determinadas relações contratuais, como nos contratos de saúde, de seguro em geral e de trabalho. Assim, pode-se concluir que a proteção à identidade genética da pessoa também está assentada na necessidade de resguardar a possibilidade de acesso ao conteúdo do seu DNA, somente legitimada quando manifestado o seu assentimento.

A lei 11.105/2005 (lei de biossegurança) proibiu, no seu art. 25, a prática da engenharia genética em célula germinal humana, zigoto ou embrião humano. No entanto, pecou o legislador ao não esclarecer a abrangência da referida previsão normativa, no sentido de deixar claro se a proibição abrange qualquer tipo de manipulação biológica e/ou terapia gênica que envolva os entes celulares identificados. É possível relacionar a questão ao foco discutido quando se identifica um direito de não ter a identidade genética alterada pela prática da engenharia genética e da terapia gênica, que podem modificar a constituição natural do patrimônio genético.

Esclarece-se que a proibição contida na lei está cingida à prática de engenharia genética e terapia gênica nas células germinativas (gametas e embriões), podendo ser realizada em células somáticas (as adultas, portanto, já desenvolvidas no corpo humano). A restrição é explicada pelo fato de que uma alteração na estrutura do DNA numa célula germinativa seria transmitida às gerações futuras, comprometendo a naturalidade do patrimônio genético em seu espectro coletivo.

Assim, a terapia gênica em células somáticas tem fulcro terapêutico e não provoca alterações genéticas transmitidas aos seus descendentes, enquanto que a a terapia gênica germinal provoca a alteração genética nas gerações futuras e ainda pode comportar-se como mecanismo de conformação de práticas eugênicas, já que não existem limites muito claros entre a proposta da terapia gênica germinal e a prática do melhoramento genético (PERTELE, 2007, p.130-131).

A identidade genética enquanto expressão da origem genética (ou biológica) de um indivíduo demanda esclarecimentos importantes ligadas à liberdade reprodutiva. Sabe-se que a existência de um ser humano está biologicamente condicionada pelo encontro de dois gametas reprodutivos que originarão o embrião que se tornará feto e posteriormente pessoa. Assim, a origem biológica do ser humano é ínsita a qualquer forma de reprodução ou a 
qualquer projeto parental procriativo. Todas as pessoas, nascidas por conjunção carnal ou por meio de procedimentos assistidos de reprodução, possuem uma origem genética, ou sejam, estão contigenciadas, no sentido celular, por um patrimônio hereditário.

O jurista português Paulo Otero explica com precisão que a ideia de identidade genética não esgota todos os aspectos concernentes à construção da identidade de uma pessoa. A identidade pessoal é genêro onde a identidade genética deve ser concebida como espécie. A noção abrangente da ideia de identidade humana (a identidade pessoal) abarca a perspectiva advinda de um referencial de natureza biológica (a identidade genética) e a perspectiva de natureza social, dinamicamente vivenciada (OTERO, 1999, p.65).

Enquanto manifestação da personalidade humana, o bem jurídico “identidade genética” deve apontar para a salvaguarda da constituição genética individual (identificação única e irrepetível de cada ser humano) enquanto referencial biológico da identidade pessoal, que está em constante construção (PERTELE, 2007, p.111).

Seguindo este traçado, pode-se compreender que a identidade genética é parte integrante da identidade da pessoa, e corresponde objetivamente ao conteúdo do DNA do indivíduo, mas pode-se estar entrelaçada à questões referentes ao conhecimento da ascendência biológica.

A conformação do direito à identidade genética então também deve abranger a possibilidade de que uma pessoa demande conhecer a sua origem biológica, ou seja, saber, quem são os seus genitores biológicos, acessando assim sua história genética. $\mathrm{O}$ acesso a essa informação, registre-se, traz polêmicos questionamentos no que tange à procriações realizadas com doação de material germinativo, sendo já reconhecido no Brasil em casos de adoção.

O artigo 48 do Estatuto da Criança e do Adolescente prevê que "o adotado tem direito de conhecer sua origem biológica, bem como de obter acesso irrestrito ao processo no qual a medida foi aplicada e seus eventuais incidentes, após completar 18 (dezoito) anos”, o que evidencia o reconhecimento normativo do direito de ter acesso à informação de ordem biológica, que se consubstancia pelo fator genético, já que não se fala em constituição de filiação.

Assim, quanto aos casos de adoção, restou reconhecido o direito de acessar a informação de cunho genético sem que isso possa configurar qualquer alteração no status de filiação já consolidada do indivíduo. A controvérsia permanece nos casos de indivíduos 
gerados por procedimentos assistidos de reprodução heteróloga, onde um doador anômino é o genitor biológico (ou genitora) da pessoa futura.

Paulo Luiz Neto Lobo aponta para existência do direito de conhecer a origem genética como um direito de personalidade sem que nada interfira na conformação de estado de filiação:

\begin{abstract}
O estado de filiação, decorrente da estabilidade dos laços afetivos construídos no cotidiano de pai e filho, constitui fundamento essencial da atribuição de paternidade ou maternidade. Nada tem a ver com o direito de cada pessoa ao conhecimento de sua origem genética. São duas situações distintas, tendo a primeira natureza de direito de família, e a segunda, de direito da personalidade. As normas de regência e os efeitos jurídicos não se confundem nem se interpenetram. Para garantir a tutela do direito da personalidade, não é necessário investigar a paternidade. O objeto da tutela do direito ao conhecimento da origem genética é a garantia do direito da personalidade, na espécie, direito à vida, pois os dados da ciência atual apontam para a necessidade de cada indivíduo saber a história de saúde de seus parentes biológicos próximos, para prevenção da própria vida (NETO LOBO, 2004, p.53).
\end{abstract}

Dessa forma, poder-se-ia também afirmar que o direito à identidade genética restaria consubstanciado pelo direito de conhecimento da origem genética, o que demandaria o repensar da conformação do contrato que envolve a reprodução humana de natureza heteróloga. A questão em si demanda melhor reflexão legal e doutrinária, na medida em que o que se discute é um novo direito de personalidade, que não se confunde com qualquer proposta de filiação e suas consequências decorrentes.

A identidade genética em sua proposta de direito ao conhecimento deve simbolizar a ponderação entre direitos envolvidos: o direito de conhecer a origem biológica pela parte do nascido e o direito de manutenção do anonimato pelo indivíduo que doou o material genético e não teria pretensão de se identificar. A questão, é provavél, deve passar por uma nova reflexão contratual, na medida em que também possa não ocasionar o esvaziamento das doações. A proposta perpassa pela compreensão do sentido da identidade genética para quem o demanda, bem como o esclarecimento quanto às consequências do exercício deste direito.

\title{
5 CONSIDERAÇÕES FINAIS
}

O acesso à informação genética é a mola propulsora do surgimento de novos direitos da personalidade, consoante ao fato de que tais direitos jamais devem concebidos como taxativos pela Ordem Jurídica. É possível pois classificar o direito à identidade genética como um novo direito de personalidade a partir da principiologia adotada pela perspectiva do direito 
civil contemporâneo, que centralizou a pessoa humana nas relações de natureza privada.

O desafio apresenta-se contínuo quando se tenta estabelecer a conformação exata do que deve ser a proteção à identidade genética, já que várias condutas podem violá-la e outros direitos restam emanharados quando se trata de acessar e/ou manipular o DNA humano.

Propõe-se que a conformação da proteção parta do direito à irrepetibilidade, cumprida pelo Estado quando proibiu a clonagem de natureza reprodutiva, evitando que pessoas sejam clonadas e tenham seu patrimônio genético repetido. Desfigura-se como legítima a proibição da clonagem de natureza terapêutica, que visa a obtenção de tecidos em órgãos, a partir do entendimento de que a conduta não viola a identidade genética de uma pessoa futura. A clonagem terapêutica tem fulcro no direito à saúde e a sua proibição evidencia incoerência se constatado que embriões humanos podem ser destinados às pesquisas científicas. Acrescente-se, inclusive, que a clonagem terapêutica tem como principal propósito servir ao indivíduo que teve seu patrimônio genético clonado, constituindo-se como uma forma de tratamento.

A identidade genética deve também ser protegida quanto ao sigilo de seu conteúdo, jamais podendo ser submetida a testes, diagnósticos ou aconselhamentos, sem consentimento do testado, e com finalidades segregacionistas, raciais ou preconceituosas. O acesso à informação genética deve ser uma realidade cingida ao seu titular e a quem este autorize.

A proteção a esta identidade também é conformada pela proibição à engenharia genética e à terapia gênica em células de natureza germinativa, tutela que ultrapassa a motivação de natureza pessoal e aponta para a proteção à coletividade, já que almeja a manutenção da integridade e da naturalidade do patrimônio genético humano.

Conclui-se, por fim, que a identidade genética também é constituída pelo direito de conhecimento do seu titular, ou seja, pela possibilidade de que o seu detentor queira conhecer a sua ascendência ou origem genética, direito já reconhecido pela lei brasileira, mais restrito aos casos de adoção. O reconhecimento da identidade genética como um direito tem como consequência a necessidade de ponderar os direitos ínsitos ao contrato de reprodução assistida heteróloga, e não admiti-lo, como vem sendo feito, levando em consideração apenas o direito ao anonimato do doador.

\section{REFERÊNCIAS}


ALCÂNTARA, Manuel J. Santos. Aspectos bioéticos del consejo genético em la era del proyecto del genoma humano. Acta Bioethica, 2004, ano X, n. 2.

BARBAS, Stela Marcos de Almeida Neves. Direito do Genoma Humano. Tese de doutoramento em Ciências Jurídicas na Universidade Autonoma de Lisboa. Coimbra: Almedina, 2007.

BARTH, Wilmar Luiz. Engenharia genética e Bioética. Revista da Pontifícia Universidade Católica do Rio Grande do Sul. Porto Alegre, v.35, n.149, set./2005. Disponível em: <www.revistaseletronicas.pucrs.br>. Acesso em: 05 jan. 2017.

BORGES, Roxana Cardoso Brasileiro. Direitos de personalidade e autonomia privada. 2.ed. rev. São Paulo: Saraiva, 2007.

CAPELO DE SOUSA, Rabindranath V.A. O Direito Geral de Personalidade. Coimbra: Coimbra Editora, 1995.

CASABONA, Carlos María Romeo. La genética y la biotecnologia en las fronteras del Derecho. Acta Bioethica, 2002, ano VIII, n.2.

CASTIEL, Luis David; CARDOSO, Maria Helena Cabral de Almeida. Saúde coletiva, nova genética e eugenia de mercado. Caderno de Saúde Pública, Rio de Janeiro, v.19, n.2, mar.abr., 2003.

DINIZ, Debora; GUEDES, Cristiano. A Ética na História do Aconselhamento Genético: um Desafio à Educação Médica. Revista Brasileira de Educação Médica, n.33, 2, 2009.

ECHTERHOFF, Gisele. Direito à privacidade dos dados genéticos. Curitiba: Juruá, 2010.

EMALDI CIRIÓN, Aitziber. El consejo genético y sus implicaciones jurídicas. BilbaoGranada: Comares, 2001.

HÄBERLE, Peter. Hermenêutica Constitucional: a sociedade aberta de intérpretes da constituição: contribuição para a interpretação pluralista e 'procedimental' da Constituição". Tradução de Gilmar Mendes. Porto Alegre: Sergio Antonio Fabris Editor, 2002.

HAMMERSCHMIDT, Denise. Intimidade genética \& Direito da Personalidade. Curitiba: Juruá Editora, 2008.

JONAS, Hans. Ética, medicina e técnica. Tradução de Antonio Fernando Cascais. Lisboa: Paimgráfica, 1994.

KUTUKDJIAN, Geoerges B. The Human Genome Project: Citizenship and Human Rights. In: GARRAFA, Volnei; PESSINI, Leo (Orgs.). Bioética: Poder e Injustiça. São Paulo: Ediçoes Loyola, 2004. 
LACADENA, Juan-Ramon. Genética y Sociedad. Madrid, 2011. Disponível em: <http://www.ranf.com/pdf/ 2011.pdf>. Acesso em: 12 jan. 2017.

LIMA NETO, Francisco Vieira. O Direito de não Sofrer Discriminação Genética. Uma nova Expressão dos Direitos da Personalidade. Rio de Janeiro: Lumen Juris, 2008.

NETO LOBO, Paulo Luiz. Direito ao Estado de Filiação e Direito à Origem Genética: Uma distinção necessária. Revista CEJ, Brasília, n. 27, p. 47-56, out./dez. 2004.

OSSWALD, Walter. Diagnóstico genético e medicina predizente. Diagnóstico prénatal. In: ASCENSÃO, José de Oliveira (Coord.). Estudos de Direito da Bioética. Coimbra: Almedina, 2005.

OTERO, Paulo. Personalidade e Identidade Pessoal e Genética do ser humano: Um perfil constitucional da Bioética. Coimbra: Almedina, 1999.

RIVERO, Jean; MOUTOUH, Hugues. Liberdades públicas. Tradução de Maria Ermantina de Almeida Prado Galvão. São Paulo: Martins Fontes, 2006.

SARLET, Ingo Wolfgang. Dignidade da pessoa humana e direitos fundamentais na Constituição Federal de 1988. Porto Alegre: Livraria do Advogado, 2001.

SCHRAMM, Fermin Roland. Eugenia, Eugenética e o Espectro do Eugenismo:

Considerações atuais sobre Biotecnociência e Bioética. Revista Bioética, CFM, Brasília, 2006. Disponível em: <www.revistabioetica.cfm.

org.br/index.php/revista_bioetica/article/viewFile/384/484> . Acesso em: 02 fev. 2017.

SCHREIBER, Anderson. Direitos da Personalidade. São Paulo: Atlas, 2011.

SEGRE, Marco; GATTÁS, Gilka Jorge Figaro; WUNSCH FILHO, Victor. Genética, biologia molecular e ética: as relações trabalho e saúde. Revista Ciência e Saúde coletiva, Rio de Janeiro, n.7, 2002.

SZANIAWSKI, Elimar. Direitos de personalidade e sua tutela. 2.ed. rev. atual., e ampl. São Paulo: Revista dos Tribunais, 2005.

PERTELE, Selma. O Direito Fundamental à Identidade genética na Constituição Brasileira. Porto Alegre: Livraria do Advogado, 2007.

POTTER, Van Rensselaer. Bioethics: Bridge to the future. New Jersey: Prentice-Hall, 1971. . Global Bioethics. Michigan: Michigan State University, 1988.

PRADO, Luis Regis; HAMMERSCHMIDT, Denise. A clonagem terapêutica e seus limites de permissibilidade na lei de biossegurança brasileira (lei 11.105/05). Anais - Conpedi 
O ACESSO À INFORMAÇÃO GENÉTICA E A CONFORMAÇÃO DOS NOVOS DIREITOS DA PERSONALIDADE: O ALCANCE DA PROTEÇÃO À IDENTIDADE GENÉTICA SOB A PERSPECTIVA DO DIREITO CIVIL CONTEMPORÂNEO

Manaus. Disponível em:

<www.conpedi.org.br/manaus/arquivos/anais/bh/denise_hammerschmidt.pdf $>$. Acesso em: 18 abr. 2017.

TEIXEIRA, Ana Carolina Brochado. Saúde, corpo e autonomia privada. Rio de Janeiro: Renovar, 2010.

TORQUATO, Bruno Naves; SÁ, Maria de Fátima Freire. Manual do Biodireito. Belo Horizonte: Del Rey. 